\title{
Alkioiden kehityksen seuranta konenäkölaitteessa
}

\section{$\bullet$}

\author{
K.Korhonen ${ }^{1}$, T.Toimela ${ }^{2}$, J.Tarvainen ${ }^{3}$, T.Suomela ${ }^{3}$, S.Sjövall ${ }^{4}$ T.Ylikomi ${ }^{2}$, J.Korpinen ${ }^{3}$, J.Viitanen ${ }^{4}$, \\ J.Vilkki $^{1}$ ja J.Peippo ${ }^{1}$ \\ ${ }^{1}$ Maa- ja elintarviketalouden tutkimuskeskus (MTT), 31600 Jokioinen ,kati.korhonen@mtt.fi \\ ${ }^{2}$ Tampereen yliopisto, Solututkimuskeskus, 33520 Tampere, \\ ${ }^{3}$ Chip-Man Technologies Oy, Biokatu 12, 33520 Tampere, \\ ${ }^{4}$ Valtion teknillinen tutkimuskeskus (VTT), Tekniikankatu 1, 33101 Tampere
}

\section{Tiivistelmä}

Alkioiden in vitro- eli laboratoriokasvatus käsittää munasolujen kypsytyksen, hedelmöityksen ja alkioiden kasvatuksen sopivissa olosuhteissa lajista riippuen 2-8 vuorokauden ikään asti, jonka jälkeen alkiot voidaan siirtää vastaanottajan kohtuun kehittymään. Nykyään alkioiden in vitro kasvatusmenetelmiä hyödynnetään monella alalla. Ihmisten hedelmällisyyshoidoissa in vitro alkioiden käyttäminen on viimeinen keino saada raskaus alulle, kun kaikki muut menetelmät on jo kokeiltu. Eläinjalostuksessa huippuyksilöistä voidaan kerätä munasoluja ultraääniavusteisesti OPUmenetelmällä, tuottaa munasoluista laboratoriossa alkioita, ja siirtää ne vastaanottajiin kehittymään lisäten näin parhaiden yksilöiden jälkeläismäärää. Tutkimuspuolella teuraseläimistä kerätyistä munasoluista tuotettuja in vitro -alkioita käytetään ihmisalkioiden mallina, ja niiden avulla kehitetään ja testataan uusia alkionkasvatus- ja pakastusmenetelmiä.

Hedelmällisyyshoidoissa ja eläinjalostuksessa vastaanottajaan pyritään siirtämään elinkyvyltään paras alkio, joka todennäköisimmin pystyy kiinnittymään kohtuun ja jatkamaan kehitystään. Nykyään valinta suoritetaan silmämääräisesti alkion ulkomuotoa, eli morfologiaa arvioimalla, vaikka menetelmä ei ole täysin luotettava. Luotettavampia alkion elinkyvyn mittareita olisivat esimerkiksi alkion kehitysnopeus ja erityisesti ensimmäisen jakautumisen ajankohta. Nykyään ei kuitenkaan ole käytössä kaupallista menetelmää, joka mahdollistaisi alkioiden kehityksen tauottoman seurannan ja sitä kautta näiden elinkyvynmittareiden hyödyntämisen.

AMMO -projektin (2006-2008) tarkoituksena on optimoida solututkimukseen kehitetty konenäkölaite Cell-IQ (Chip-Man Technologies Oy) naudan alkioiden avulla alkiokasvatuksiin ja seurantaan sopivaksi. Tämän laitteen avulla alkioiden kehityksen tauoton seuranta olisi mahdollista, ja lisäksi laitteen ohjelmistoa kehittämällä arviointitehtäviä, jotka nykyisin suorittaa ihminen mikroskoopin avulla, voitaisiin siirtää laitteen tehtäväksi.

Tähän mennessä konenäkölaitteen olosuhteet on saatu optimoitua, ja alkioiden kasvatus ja kuvaaminen laitteessa onnistuu. Ohjelmiston kehitystyö on aloitettu yhdessä Chip-Man Technologies Oy:n kanssa käyttäen apuna laitteella otettuja alkiokuvia. Tällä hetkellä laite tunnistaa alkiot ja pystyy erottamaan tiettyjä kehitysvaiheita. Ohjelmistoon tullaan mahdollisesti tulevaisuudessa liittämään myös alkioiden 3D-mallinnus, jota VTT kehittää yhdessä MTT:n ja Tampereen yliopiston kanssa. Projektissa ovat mukana myös BioTech Visions Oy, Alkiokeskus Oy, Regea, Väestöliitto ja AVAklinikka yrityspartnereina, ja mahdollisesti tulevaisuudessa uuden teknologian hyödyntäjinä.

Tavoitteena on kehittää konenäkölaite, jonka avulla alkioiden valinta voidaan suorittaa paitsi morfologisen arvioinnin, myös kehitysnopeuden perusteella. Laitteen avulla alkioiden valinta elinkyvyn perusteella tarkentuu, syntyvien jälkeläisten lukumäärä kasvaa ja eläinjalostus tehostuu. Laitetta käytetään jo tällä hetkellä myös ihmisalkioiden ja munasolujen tutkimukseen hedelmällisyyshoitoja tarjoavilla klinikoilla. Tutkimuspuolella konenäkölaite mahdollistaa esimerkiksi erilaisten alkionkasvatusliuosten vaikutusten tarkastelun aiempaa tarkemmin.

Asiasanat: in vitro -alkiotuotanto, ihminen, nauta 


\section{Johdanto}

AMMO -projektin tavoitteena on optimoida soluviljelyyn kehitetty konenäkölaite alkioiden kasvatukseen ja seurantaan sopivaksi. Laitteen kehitystyössä ihmisen alkioiden käyttäminen ei ole mahdollista, joten optimoinnit tehdään ihmisen alkioita hyvin vastaavilla naudan alkioilla.

Nykyään käytössä olevat in vitro -alkiokasvatusmenetelmät ovat perusteiltaan samanlaiset riippumatta lajista. Alkioiden kasvatusympäristö pidetään mahdollisimman muuttumattomana kasvatuskaapin avulla niin, että lämpötila (ihminen $+37{ }^{\circ} \mathrm{C}$, nauta $+39{ }^{\circ} \mathrm{C}$ ), suhteellinen ilmankosteus 100\%, ja kaasukoostumus 5\% $\mathrm{O}^{2}-5 \% \mathrm{CO}^{2}-90 \%$ N2 ovat oikeat. Lähtömateriaali, eli munasolut saadaan keräystavasta riippuen joko kypsinä - jolloin ne ovat valmiita hedelmöitettäviksi - tai epäkypsinä, jolloin ne täytyy ennen hedelmöitystä kypsyttää 24 h. Munasolujen kypsytysliuokseen, jonka perusliuoksena toimii soluviljelyliuos, lisätään hormoneja ja proteiinia, jotka tukevat munasolun tuman ja soluliman kypsymistä. Kypsymisen aikana munasolun tuma siirtyy meioosin vähennysjaon alusta meioosin tasausjaon alkuun, ja solulimassa tapahtuu soluorganellien uudelleen järjestäytymistä. Kypsytyksen jälkeen munasolut hedelmöitetään 18-20 h. Hedelmöitetyistä munasoluista poistetaan kumulussolut ja ne siirretään viljelypisaroihin, joissa ne kasvavat aina 2-9 vuorokauden ikään asti. Naudan alkioita tarkastellaan viljelyn aikana neljässä aikapisteessä: 4 vuorokauden kohdalla tarkastetaan kuinka suuri osa hedelmöitetyistä munasoluista on jakautunut, ja 7, 8 ja 9 vuorokauden kohdalla tarkastetaan alkioiksi kehittyneiden munasolujen osuus. Tarkastelun ajaksi alkiot otetaan ulos kasvatuskaapista huoneilmaan, ja altistetaan mikroskoopin voimakkaalle valolle. Tarkastelun aikana ilman kasvatuskaappia alhaisempi hiilidioksidipitoisuus muuttaa viljelyliuosten pH-tasoa, liuosten lämpötila muuttuu ja valo saa aikaan vapaiden radikaalien muodostumista soluissa. Alkiot joutuvat siis stressitilaan aina kun ne otetaan ulos kasvatuskaapin optimaalisesta ympäristöstä.

Nykyään alkioiden elinkyvyn arviointi suoritetaan pääasiassa alkion morfologiaa arvioimalla. Alkion kehitysvaihe päätellään solumassan tiiviyden, ontelon koon, sisäsolumassan koon ja alkiokuoren paksuuden perusteella, ja alkion laatu kuolleen solumassan osuuden ja alkion muodon perusteella. On kuitenkin todettu, että alkio voi näyttää morfologisesti hyvältä, olematta kuitenkaan elinkykyinen, tai päinvastoin (Enders ym. 1989). Morfologisen arvioinnin sijasta olisi mahdollista käyttää alkioiden kehitysnopeutta, sillä se on todettu useissa tutkimuksissa hyväksi alkion elinkyvynmittariksi (Van Soom ym. 1997b, Rieger ym. 1999, Dinnyes ym. 1999). Ensimmäinen jakautuminen hedelmöityksen jälkeen, alkion solumassan tiivistyminen eli kompaktoituminen morulavaiheessa ja nesteen täyttämän ontelon muodostuminen alkion sisälle blastokystivaiheessa ovat muutoksia joiden tarkka ajankohta siis halutaan selvittää. Esimerkiksi ensimmäisen jakautumisen pitäisi tapahtua naudan alkioissa 27-30 tunnin kuluttua hedelmöityksestä, muuten alkionkehityksessä on todennäköisesti häiriöitä (Rieger ym. 1999). Alkioita ei kuitenkaan voida ottaa ulos kasvatuskaapista kovin usein, joten kehitysnopeuden seuraaminen ilman jatkuvasti tallentavaa laitetta kasvatuskaapin sisällä on mahdotonta.

Ensimmäinen videomikroskooppi alkioiden seurantaan kehitettiin jo 1950-luvun lopulla (Blandau ja Rumery 1957). Sen jälkeen erilaisia konenäkölaitetta muistuttavia menetelmiä on kehitetty tutkimuskäyttöön, mutta ne ovat työläitä käyttää, eikä niissä ole mahdollisuutta alkioiden seurannan ja arvostelun automaattiseen analysointiin. Konenäkölaite Cell-IQ on soluviljelmien kasvatusta ja seurantaa varten Tampereella kehitetty laite, jota käytetään tällä hetkellä esimerkiksi toksikologisissa testeissä ja lääketutkimuksessa. Laite on helppokäyttöinen ja siinä on ohjelmisto, joka mahdollistaa kuvien tallentamisen ja muokkauksen. Ohjelman kykyä tunnistaa alkioita ja niiden kehitysvaiheita pyritään kuitenkin vielä parantamaan kehitteillä olevalla, ohjelmaan mahdollisesti liitettävällä 3Dmallinnuksella. 3D-ominaisuus on tärkeä alkioiden pyöreän muodon takia, sillä esimerkiksi kehitysvaiheen tunnistamisen kannalta tärkeä sisäsolumassa saattaa olla alkion alla, ja pelkkää 2Dkuvaa käyttämällä ohjelma ei pystyisi näitä alkioita luotettavasti arvostelemaan. 


\section{Aineisto ja menetelmät}

Konenäkölaite Cell-IQ on Chip-Man Technologies Oy:n, VTT:n ja Tampereen yliopiston solututkimuskeskuksen yhteistyössä kehittämä laite (mm. SOLOMANDA -projekti). Se koostuu kasvatuskammiosta, jonka sisään on rakennettu mikroskooppi (Nikon light source, Nikon 10x objective) ja kamera (Jai cv-A10CL), sekä kameraan liitetystä tietokoneesta. Tietokoneessa on ChipMan Technologies Oy:n kehittämä ohjelmisto, jonka avulla kuvat tallennetaan, analysoidaan, ja niitä voidaan tarvittaessa yhdistää videoiksi. Kasvatuskammion lämpötilaa ja kaasukoostumusta voidaan myös säätää ohjelman avulla.

Konenäkölaitteen optimointia varten tuotettiin naudan alkioita seuraavasti: Teurastamolta haetuista munasarjoista kerättiin munasolut neulan ja ruiskun avulla, jonka jälkeen munasoluja kypsytettiin 24 h kypsytysliuoksessa (koostumus: M199-liuos jossa Glutamax-I:stä (Gibco $^{\mathrm{TM}}$ Invitrogen Corporation), 0,25mM Na-pyruvaattia, $100 \mathrm{IU} / \mathrm{ml}$ penisilliiniä, $100 \mu \mathrm{g} / \mathrm{ml}$ streptomysiiniä ja $10 \mathrm{ng} / \mathrm{ml} \mathrm{hFSH}$ (Puregon)) kasvatuskaapissa $+39{ }^{\circ} \mathrm{C}, 5 \% \mathrm{CO}_{2}$. Kypsytyksen jälkeen munasolut hedelmöitettiin pakastesiittiönesteellä (Kalliolan Istoh) kasvatuskaapissa $22 \mathrm{~h},+39{ }^{\circ} \mathrm{C}, 5 \% \mathrm{CO}_{2}$. Siittiöneste pestiin ennen käyttöä sentrifugoimalla (100G, 6 min) sitä kahdesti Sperm-talp -liuoksessa (Parrish ym. 1988). Munasolut siirrettiin kahden pesun kautta (Flushing medium $+1 \mathrm{mg} / \mathrm{ml} \mathrm{BSA}$; IcpBio) kypsytysliuoksesta IVF-talp -liuokseen (Parrish ym. 1988), johon lisättiin pesty siittiöneste niin, että siittiötiheydeksi tuli $10^{6} / \mathrm{ml}$. Hedelmöityksen jälkeen munasoluista poistettiin ympäröivät kumulussolut vorteksoimalla (nopeus 7, 2 min), ne jaettiin kahteen ryhmään (MTT ja TaY) ja siirrettiin kasvatusmaljoille viljelypisaroihin (G1-liuos; Vitrogen). Toinen maljoista jätettiin MTT:een kasvatuskaappiin kontrolliryhmäksi ja toinen kuljetettiin Tampereelle konenäkölaitteeseen. Viljelyympäristön lämpötila $+39{ }^{\circ} \mathrm{C}$ ja kaasukoostumus $5 \% \mathrm{O}_{2}, 5 \% \mathrm{CO}_{2}, 90 \% \mathrm{~N}_{2}$ pidettiin samana koko kasvatuksen ajan. Neljän vuorokauden kuluttua hedelmöityksestä alkiot siirrettiin uusiin viljelypisaroihin (G2-liuos; Vitrogen), joissa ne kasvoivat 8 vuorokauden ikään asti. Alkioiden kehitystä tarkasteltiin MTT:lla 4, 7 ja 8 vuorokauden kuluttua hedelmöityksestä. Konenäkölaitteessa alkioita kuvattiin joka 15. minuutti. Alkiokasvatusten onnistumista arvioitiin alkiotuotantoteholla, joka laskettiin jakamalla päivänä 8 alkioiksi (kompaktoituneet morulat - kuoriutuneet blastokystit) kehittyneiden munasolujen lukumäärä viljelyyn laitettujen munasolujen lukumäärällä. Yleensä naudan in vitro -alkiotuotantoteho on $\mathrm{n} .30 \%$. Kehittyneet alkiot kerättiin arvostelun jälkeen viljelymaljalta Holding -liuokseen (IcpBio), pestiin 4x PBS-PVP:ssa ja kerran RNAasi-säilytysliuoksessa, jonka jälkeen alkiot pakastettiin näytteiksi jatkotutkimuksia varten.

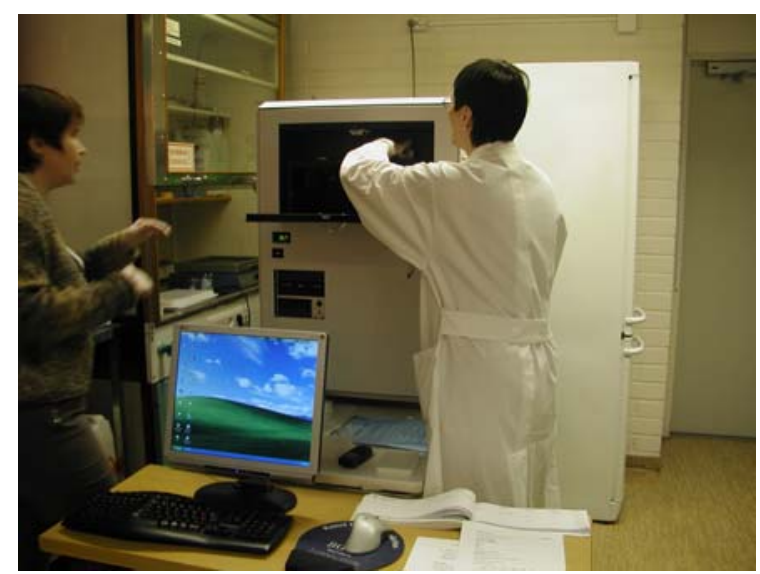

Kuva 1. Konenäkölaitteen kasvatuskammioon ollaan asettamassa alkiokasvatusmaljaa.

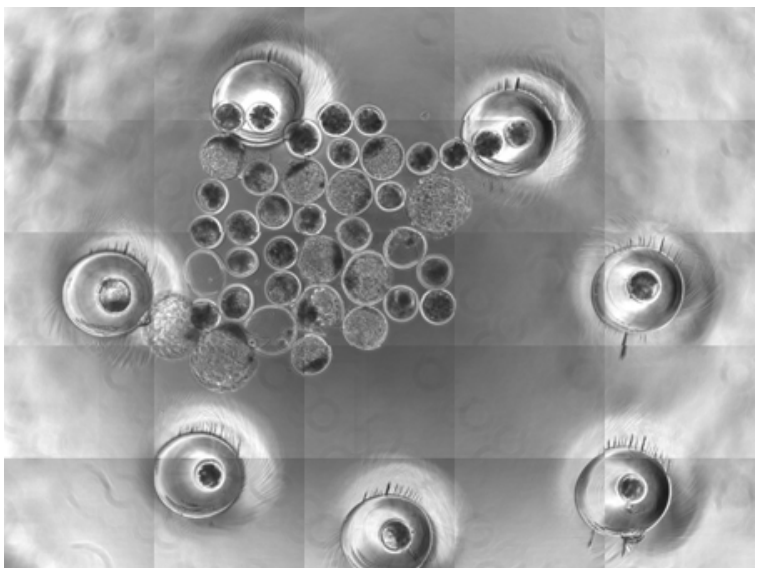

Kuva 2. 8 vuorokauden ikäisiä konenäkölaitteessa kasvatettuja ja kuvattuja naudan alkioita. 


\section{Tulokset ja tulosten tarkastelu}

\section{Konenäkölaitteen optimointi}

Konenäkölaitteen optimoinnin aikana laitteen kasvatuskammion säätöjä muutettiin alkioiden kasvuympäristöä vastaavaksi. Lämpötila säädettiin $+39{ }^{\circ} \mathrm{C}$ asteeseen, viljelykaasuksi vaihdettiin seoskaasu ja kaasunvirtausta muutettiin. Erilaisia viljelypisaratilavuuksia ja kasvatusmalja vaihtoehtoja testattiin. Alkioryhmän liikkumista kasvatuksen aikana estettiin tekemällä kasvatusmaljan pohjaan kuoppia, jotka näkyvät kuvassa 2 renkaana alkioryhmän ympärillä. Ohjelmaa "opetettiin” tunnistamaan alkiot ja tiettyjä kehitysvaiheita, ja myöhemmin jatketaan mahdollisesti erilaisten laatuluokkien tunnistamisella. Ohjelman asetuksia myös muutettiin muodoltaan pyöreiden alkioiden kuvaamiseen sopiviksi, sillä ohjelma on kehitetty alunperin tekemään tarkka kuva litteistä soluista.

3D-mikroskopian osalta on toistaiseksi tutkittu kaupallisten dekonvoluutiomenetelmien soveltuvuutta tehtävään. Ne parantavat erityisesti fluoresenssileimoja hyödyntävien 3Dmikroskooppikuvien syvyysresoluutiota, mutta alkioiden kohdalla ei luonnollisesti voida käyttää tällaisia leimoja, joten dekonvoluution tuomat hyödyt osoittautuivat marginaalisiksi. Tyypilliset 3Dmikroskopian kuvantamismenetelmät käyttävät lisäksi suuren intensiteetin laservalaisua, joten ne saattavat olla vahingollisia alkioille. 3D-mikroskopian kehittämiseksi näyttääkin lupaavimmalta usean eri menetelmän yhdistämiseen perustuva lähestymistapa, soveltuvia menetelmiä voivat olla $\mathrm{mm}$. tarkennusepäterävyyden hyödyntäminen, syvyyssuunnassa selektiivisen valaisun käyttö, liikkeen hyväksikäyttö (pseudostereo tai kuvasta laskettujen liikevektorien hyödyntäminen parallaksin mittaamiseksi). Tätä varten VTT:n laboratorioon on rakennettu testimikroskooppi, jossa on mahdollista testata erilaisia suunnattuja valaisumenetelmiä, varioida kuvauskulmaa kasvatusmaljan pohjaan verrattuna, pyörittää kohdetta tietokoneen ohjaamana, sekä motorisoidun fokusoinnin avulla sektioida näkymää kuvaussuunnassa.

\section{Alkiokasvatustulokset}

Laitteen optimoinnin jälkeen alkiotuotantoteho 8 vuorokauden kuluttua hedelmöityksestä ei näyttänyt eroavan kasvatuskaapin ja konenäkölaitteen välillä. Alkiot kuitenkin kehittyivät konenäkölaitteessa hitaammin kuin kasvatuskaapissa, mikä näkyy alhaisempana alkiotuotantona 7 vuorokauden kuluttua hedelmöityksestä. Selvää syytä alkiokasvatustulosten eroihin menetelmien välillä ei löydetty, vaikka alkioiden kuvaamisen, konenäkölaitteen liikkeen, happipitoisuuden ja alkioiden kuljetuksen vaikutuksia tarkasteltiin. (Taulukko1)

Taulukko1. Alkiotuotantoteho konenäkölaitteessa Tampereella ja kasvatuskaapissa Jokioisilla.

\begin{tabular}{lcc}
\hline & Alkio\% 7 vrk & Alkio\% 8 vrk \\
\hline Konenäkölaite & 19 & 27 \\
Kasvatuskaappi & 28 & 31 \\
\hline
\end{tabular}

Alkio\% on laskettu kasvatukseen laitetuista hedelmöitetyistä munasoluista. 


\section{Johtopäätökset}

Konenäkölaitteen kasvatusolosuhteiden optimointi naudan alkioita mallina käyttäen onnistui, vaikka eroja kasvatuskaapin alkiotuotantotuloksiin on edelleen esimerkiksi alkioiden kehitysnopeudessa. Laite sopii kuitenkin jo nyt naudan alkioiden kasvatukseen ja arviointiin, joten konenäön avulla voidaan kerätä tarkempaa tietoa naudan alkioiden kehityksestä esimerkiksi erilaisissa tutkimushankkeissa. Nyt projektissa ollaan valmiita siirtymään seuraavaan vaiheeseen, eli laitteessa on tarkoitus kasvattaa ja kuvata tutkimuskäyttöön lahjoitettuja ihmisen alkioita.

Tärkein konenäkölaitteen tuoma uusi mahdollisuus on alkioiden kehityksen tauoton seuranta, jolloin alkioiden elinkykyä voidaan luotettavammin arvioida. Lisäksi laitteen mikroskoopin valaisua voidaan ohjata siten, että se on päällä vain muutaman milisekunnin ajan kuvanoton yhteydessä, jolloin alkioiden valoaltistus minimoidaan verrattuna ihmisen suorittamaan, usean minuutin ajan kestävään visuaaliseen tarkasteluun. Konenäkölaitteen ohjelman kehitystyö on vielä kesken, mutta jos se onnistuu odotusten mukaisesti, kone pystyy tulevaisuudessa tunnistamaan ihmisen puolesta tärkeitä alkionkehityksen vaiheita, kuten ensimmäinen jakautuminen ja blastokystiontelon muodostuminen. Konenäkölaite mahdollistaa alkioteknologian ja sitä kautta eläinjalostuksen kehittämisen, sekä mahdollisesti tulevaisuudessa hedelmällisyyshoitojen tehostamisen.

\section{Kirjallisuus}

Blandau, R.J. \& Rumery, R.E. 1957. The attachment cone of the guinea pig blastocyst as observed under timelapsed cinematography. Fertil. Steril. 8:570-585.

Dinnyes, A., Lonergan, P., Fair, T., Bolnad, M.P. \& Yang, X. 1999. Timing of the first cleavage postinsemination affects cryosurvival of in vitro produced bovine blastocysts. Mol. Reprod. Dev. 53:318-324.

Enders, A.C., Boatman, D., Morgan, P.M. \& Bavister, B.D. 1989. Differentiation of blastocysts derived from in vitro fertilized rhesus monkey ova. Biol. Reprod. 41:715-727.

Parrish, J.J., Susko-Parrish, J., Winer, M.A. \& First, N.L. 1988. Capacitation of bovine sperm by heparin. Biol. Reprod. 38:1171-1180.

Rieger, D., Grisart, B., Semple, E., Van Langendonckt, A., Betteridge, K.J. \& Dessy, F. 1995. Comparison of the effects of oviductal cell co-culture and oviductal cell-conditioned medium on the development and metabolic activity of cattle embryos. J Reprod. Fert. 105:91-98.

Van Soom, A., Ysebaert, M.T. \& de Kruif, A. 1997b. Relationship between timing of development, morula morphology and cell allocation to inner cell mass and trophectoderm in vitro-produced bovine embryos. Mol. Reprod. Dev. 47:47-56. 